\title{
Investigating the Effect of External Alliances on Innovation Behavior in the European Union Industrial Sector
}

\author{
Zu'bi M. F. Al-Zu'bi \\ School of Business, The University of Jordan, Amman, Jordan \\ Email: z.alzubi@ju.edu.jo
}

Received 6 February 2016; accepted 23 February 2016; published 26 February 2016

Copyright (C 2016 by author and Scientific Research Publishing Inc.

This work is licensed under the Creative Commons Attribution International License (CC BY). http://creativecommons.org/licenses/by/4.0/

c) (i) Open Access

\begin{abstract}
The purpose of this study is to investigate the effects of collaboration with suppliers and lead users in new product development (NPD) on innovation behavior. Such collaborations are regarded as advanced forms of external alliances. Survey data from two hundred and fifty-two manufacturing companies were collected from the European Union. The results of multiple regression analysis showed that both suppliers' and lead users' collaboration in NPD significantly affected innovation behavior. Lead users' collaboration showed higher impact on innovation behavior compared with suppliers' collaboration.
\end{abstract}

\section{Keywords}

Suppliers Collaboration, Lead Users Collaboration, External Alliances, Innovation Behavior, EU

\section{Introduction}

Interest in new product development has garnered much recent attention from both academics and practitioners, driven by increasing market competition, changing customer demands, and increasing environmental uncertainty [1]. Additionally, globalization has forced companies to pay considerable attention to innovation as a key competitive advantage. Innovation enables companies to introduce new products that are desired by consumers, to reduce production costs and improve production processes [2]. An important approach to capturing innovation was introduced by [3], who found that innovation was dependent on external sources and external partners for new ideas. Innovation behavior was considered a potential enabler that could modernize the concept of innovation, by opening up to consumers and suppliers alike.

External innovation offers an alternative to the traditional methods practiced by companies in the past, in 
which it was assumed that the innovation process was best controlled by the company itself. Firms would hire the brightest minds available, invest heavily in their research and development (R\&D) departments, and protect the resulting products through trademarks and patents. Profits would then be re-invested into R\&D, and the cycle would repeat [4]. The utility of an internal R\&D department does result in lower organization costs by streamlining innovation processes and gaining economies of scale and scope for R\&D. In addition to developing new products, an internal R\&D department also had the ability to track, evaluate, and absorb new developments outside of the firm [5].

However, the current age of rapid globalization posed new demands to companies that internal innovation could not meet. The availability of a greater population of educated people across the globe, who were increasingly mobile and able to share and communicate swiftly, using technology, put an end to the monopoly of internal innovation. Furthermore, the days of employees remaining with the same company for their entire career were over, with modern professionals more likely to be seeking a varied portfolio. As a result, there was much greater capacity for fresh ideas regarding innovation. Moreover, new innovative ideas are not restricted to internal use by the developing organization. Those ideas can be sold to other firms in the same industry or other industries [4] [6].

Firms no longer need to directly employ leading intellectuals, or directly create "valuable" research, in order to make a profit. New product development (NPD) can be leveraged from another firm's budget, and a more innovative culture can be created from the outside, through exposure to external innovators. External innovation also brings profit from knowledge and new technology of internal R\&D through external paths to the market. Such factors contribute to innovation performance and add incentives to organizations to increase their innovation efforts [7] [8].

External collaboration is widely referred to as an enabler of new product development [2] [9]. Previous research indicated that NPD projects had higher success rates with external collaboration. Such external collaboration cuts costs and time needed to develop a new product [10]. In addition, recent research pointed to the important role of engaging lead users in NPD projects [9]. Increased competition and environmental dynamism have forced companies to pay a considerable attention to such collaborations with suppliers and lead users. The mobility of knowledge among those partners may accelerate and facilitate the innovation process [9] [11]. Though previous studies have highlighted the role of such collaborations [12] [13], it is still unclear how both supplier and lead user collaboration in NPD may affect innovation behavior.

In this study, six main dimensions were used to measure the companies' innovation behavior: new product quality, new product cost, new product reliability and security, quality of process innovation performance, effectiveness of process innovation performance, speed of process innovation performance, and projects successful implementation. The expected contribution of the current research is to highlight the relative contribution of the external alliances with suppliers and lead users on innovation behavior. Such a contribution will have academic and practical implications. This could assist consumer products manufactures in introducing new and demanded products to the market before rivals, thus providing a sustainable competitive advantage.

\section{Framework and Conceptual Development}

\subsection{Research Framework}

The framework for this research shows the effects of collaboration with supplier and lead users in NPD on innovation behavior this will be thoroughly discussed in the next sections:

\subsection{Conceptual Development}

\subsubsection{Related Literature}

Innovation behavior is a multistage process that involves various activities and individuals at each stage. In external innovation, individuals can be involved in any activity or behavior at any time [14]. The fundamental ideas behind external innovation are not new, as innovation has always involved some external influence. Organizations have traditionally relied on new innovative ideas to increase their competitive advantage and profitability [6] [7] [10]. Similarly, as proposed by [15], R\&D departments have never been completely segregated from outside influences. Here, we define external innovation as a more concerted and expansive approach to external collaboration and commercialization. Chesbrough [3] described innovation as "both a set of practices for 
profiting from innovation, and also a cognitive model for creating, interpreting, and researching these practices”. This definition bridges a number of ideas and practices and makes innovation applicable to a large number of industries.

Innovation behavior has undergone significant evolution, from a "small club of innovation practitioners" in predominantly high-tech industries to a following in a range of industries [4]. Research on the subject escalated in the first decade of the second millennium, leading to largely increased and deeper knowledge of innovation [6] Solitary lectures have grown to series of large, well-attended seminars across the globe [3] Innovation behavior, with a particular focus on external innovation, is now practiced across a wide range of industries, remaining embedded in industries that were at the forefront of the movement, such as software development and electronics, while penetrating various "pioneer industries" such as pharmaceuticals manufacturing and biotechnology. For example, Bayer’s Creative Centre, Eli Lilly’s Incentive Initiative, and Pfizer’s in-licensed drug and the profitable drug Lipitor are results of innovation.

The ongoing search for sustainable competitive advantage is the main reason companies push NPD initiatives in the consumer products industry. The brisk growth in consumer-varied demand concomitant and even shorter product life cycles has pressed companies to look toward different methods for developing new products. In many cases, organizations acquired the necessary skills and technology through collaboration with external partners. Moreover, such collaboration reduces costs, enhance product performance, and increase overall efficiency [16]-[19].

Given the undisputed importance of innovative behavior, there is much interest in identifying which partners are the most effective source of innovation behavior. Von Hippel [20] asserted that lead users contribute most to innovation as they enhance operational sources of innovation according to real market needs. Other academicians assert that suppliers are the most contributing party to innovation behavior as they have the knowledge, technology, and several new ideas [21]-[23]. The latter viewpoint relied on the resource-based view theory to explain the powerful role of suppliers in NPD projects through sharing the knowledge and expertise they have with the buying firm [1] [24] [25]. Despite the each stream of research insisting an important role for one external partner in NPD, relatively fewer comparative studies have been reported.

Recent literature has paid attention to the role of external collaborators in NPD. Attention was given to the quality of proposed new ideas and the performance of new products. Formal and informal relationships were considered by researchers [26]. Such relationships, either with suppliers or customers, provide the firm with additional knowledge and resources enhancing, thus, its competitive position [6] [10]. This study emphasizes that innovation behavior will be positively affected by collaborating with suppliers and lead users in NPD. Though the literature argued that lead users are expected to have higher impact on innovation behavior relative to suppliers, there is not yet any evidence concerning the impact of the two partners on innovation behavior.

\subsubsection{Suppliers' Collaboration and Innovation Performance}

Previous literature in the area of the supply chain pointed to the role of suppliers in fostering NPD projects [21] [23]. Supplier selection is argued to affect NPD collaboration as closed and qualified suppliers are expected to enhance innovativeness and performance of new products [1]. Additionally, for such a collaboration to be successful, both parties should share potential benefits [6] [27] [28]. Also, suppliers may assist in the technological and marketing efforts needed for new products [1] [29]. While it is risky to share internal knowledge and resources with external suppliers, the benefits of trusted suppliers are expected to leverage such risks. Despite the benefits reported in the literature, disadvantages of such collaboration were also reported. In some cases logistical constraints may impede the effectiveness of NPD collaboration. Moreover, the risk of sharing critical knowledge may restrict effective collaboration. Many companies hesitate of sharing knowledge related to their core competencies. Other constraints are related to internal employees who used to work with internal teams within the organization and who may not be open enough to external teams from the supplier firms [30]. Furthermore, objectives of the two partners may contradict accompanied with different capabilities and strategies [12]. Such situation may lead to longer NPD times due to the need to standardize processes and working procedures [31] [32].

Previous research concentrated on measuring the effect of supplier collaboration on performance in terms of time, quality and cost. Though those measures are important, innovation behavior is a more accurate measure of the effectiveness of such collaboration. All in all, suppliers with their technological capability, their deep knowledge of the market and customer needs are expected to enhance innovation behavior, leading to the first hypo- 
thesis:

H1: Supplier collaboration in NPD will be positively and significantly related to innovation behavior

\subsubsection{Lead Users' Collaboration and Innovation Behavior}

Von Hippel defined lead users as a specialised group of consumers who experience heightened and pre-emptive market needs, and therefore often suggest innovative bespoke solutions [20]. Research has pointed to lead users as an essential source of capturing the expectations and needs of markets. Their deep knowledge of the market offers an opportunity to overcome competitors with regard to innovative new products [33] [34]. Lilien asserted that lead users are the primary source of innovation, proposing a framework to facilitate their engagement in NPD projects [35]. As with suppliers, contradicting objectives between the firm and lead users may potentially impede successful collaboration between the two parties. Some studies pointed to the importance of having common objectives, visions, and capabilities in order to achieve desired results [1] [20] [36]. Others cited various benefits of lead user collaboration in NPD including reduced cycle times, improved quality and efficiency, reduced development times and decreased costs [37] [38].

Some researchers have argued that lead users collaboration increases the risk of leaking internal knowledge, and can increase cost and development time. Additional disadvantages reported in the literature included the negative impact of such collaboration on inter-firm routines and procedures, and a dependency of customers that may frustrate internal teams [39] Moreover, it was argued that such collaboration may limit the innovation to be incremental [6] [30]. However, despite these challenges, most researchers believe that lead users are expected to enhance innovation behavior and increase company's competitive advantage. Based on the above arguments, the following hypothesis is proposed:

H2: Lead users collaboration in NPD will be positively and significantly related to innovation behavior

\section{Methodology}

\subsection{Data Collection}

A survey was used to collect data for this study. Respondents were asked to answer question items using 5 point Likert scale with 5 pointing to strong agreement and 1 pointing to strong disagreement. Well-tested scales were adopted from the literature to ensure face and content validity. The constructs for supplier and lead users collaboration in NPD were adapted from Abdallah [40], while the construct for innovation behavior was adapted from Tang et al. [41]. The constructs were pilot tested by three professors of business management, and items revised based on their recommendations. The population of this research consisted of manufacturing companies in the European Union (EU), with this survey targeting 450 local and multinational manufacturing companies operating in the EU's industrial zones. The questionnaire was sent by e-mail to the selected companies. The unit of analysis represented one of the following managers: NPD manager, operations manager, or plant manager. A total of 275 questionnaires were returned, with 23 of these excluded from further analysis due to missing data, giving 252 usable questionnaires. This response rate, of 56\%, is regarded as high for studies using e-mail to collect data, and is in fact close to values reported for studies that used personal visits to collect data.

\subsection{Measurement Analysis}

In order to ensure construct validity, exploratory factor analysis (EFA) was used [42], with criteria defined to ensure that all items for a construct loaded onto one factor with a factor loading greater than 0.40 and eigenvalue greater than 1. Moreover, the Varimax rotation method was used [42]. It is recommended to perform KaiserMeyer-Olkin (KMO) test for assessing sampling adequacy and Bartlett's test of sphericity to test for homogeneity of variances [42]. The two tests were conducted and the results confirmed the appropriateness of data for further analysis.

The reliability of the constructs was tested using Cronbach's $\alpha$-coefficient. All the three scales showed a reliability of $\alpha \geq 0.70$ indicating an acceptable reliability and internal consistency (Hair et al., 2010). The mean values, standard deviations, and Cronbach's alpha values are reported in Table 1.

The results of EFA are shown in Table 2. Eight question items measured supplier collaboration in NPD, Eight items measured lead users collaboration in NPD, and seven question items measured innovation behaviour construct. 
Table 1. Means, standard deviations, and Cronbach’s $\alpha$-coefficient.

\begin{tabular}{ccccc}
\hline Variable & Mean & Standard deviation & $\begin{array}{c}\text { Cronbach's } \\
\alpha \text {-coefficient }\end{array}$ & $\begin{array}{c}\text { Final number of } \\
\text { question items }\end{array}$ \\
\hline 1. Supplier collaboration & 3.51 & 0.436 & 0.764 & 8 \\
2. Lead users collaboration & 3.62 & 0.512 & 0.784 & 8 \\
3. Innovation behaviour & 3.76 & 0.478 & 0.716 & 7 \\
\hline
\end{tabular}

Table 2. Exploratory factor analysis.

\begin{tabular}{|c|c|c|c|c|}
\hline \multirow{8}{*}{$\begin{array}{l}\text { Supplier } \\
\text { collaboration }\end{array}$} & We consult suppliers early in the design efforts for new products. & 0.300 & 0.703 & 0.031 \\
\hline & We partner with suppliers for the design of new products. & 0.212 & 0.707 & -0.030 \\
\hline & Suppliers are frequently consulted about the design of the new products. & 0.101 & 0.809 & 0.045 \\
\hline & $\begin{array}{l}\text { Suppliers are involved in the new product project only after the design } \\
\text { is completed. }\end{array}$ & 0.191 & 0.888 & 0.054 \\
\hline & Suppliers are an integral part of the design effort for the new products. & 0.098 & 0.900 & 0.077 \\
\hline & $\begin{array}{l}\text { Suppliers are involved in specifying product specifications for the } \\
\text { new products. }\end{array}$ & 0.199 & 0.834 & 0.073 \\
\hline & Suppliers are consulted in setting general new product definition. & 0.190 & 0.765 & 0.072 \\
\hline & Suppliers are involved in the new product process from the start to the finish. & 0.200 & 0.799 & 0.091 \\
\hline \multirow{8}{*}{$\begin{array}{l}\text { Lead users } \\
\text { collaboration }\end{array}$} & We consult lead users early in the design efforts for new products. & 0.890 & 0.111 & 0.049 \\
\hline & We partner with lead users for the design of new products. & 0.888 & 0.112 & 0.046 \\
\hline & Lead users are frequently consulted about the design of the new products. & 0.824 & 0.134 & 0.034 \\
\hline & $\begin{array}{l}\text { Lead users are involved in the new product project only after the design is } \\
\text { completed. }\end{array}$ & 0.722 & 0.293 & 0.033 \\
\hline & $\begin{array}{l}\text { Lead users are involved in specifying product specifications for the } \\
\text { new products. }\end{array}$ & 0.900 & 0.099 & 0.064 \\
\hline & Lead users are an integral part of the design effort for the new products. & 0.733 & 0.154 & 0.028 \\
\hline & Lead users are consulted in setting general new product definition. & 0.654 & 0.197 & 0.049 \\
\hline & Lead users are involved in the new product process from the start to the finish. & 0.911 & 0.077 & 0.150 \\
\hline \multirow{7}{*}{$\begin{array}{l}\text { Innovation } \\
\text { behaviour }\end{array}$} & My company has better new product quality than others & 0.213 & 0.075 & 0.751 \\
\hline & My company has better new product cost than others & 0.101 & 0.170 & 0.805 \\
\hline & My company has better new product reliability and security than others & 0.111 & 0.122 & 0.779 \\
\hline & My company has better quality of process innovation performance than others & 0.056 & 0.059 & 0.897 \\
\hline & $\begin{array}{l}\text { My company has better effectiveness of process innovation performance than } \\
\text { others }\end{array}$ & 0.072 & 0.212 & 0.700 \\
\hline & My company has better speed of process innovation performance than others & 0.181 & 0.104 & 0.891 \\
\hline & My company has better Projects successful implementation than others & 0.151 & 0.126 & 0.785 \\
\hline
\end{tabular}

Extraction method: Principal component analysis. Rotation method: Varimax with Kaiser Normalisation.

\section{Results and Analysis}

Multiple regression analysis was used to test the study hypotheses. Normality tests showed that skewness ranged between -0.134 and 0.173 , indicating that the data is normally distributed [42]. Multicollinearity is a potential problem that may affect the results due to highly correlated independent variables. The variance inflation factor (VIF) method was used to test for potential effect of multicollinearity, and the measured VIF values for the independent variables were all below 1.2, indicating that multicollinearity did not affect the results of the analysis [42]. 
Control variables were entered first in the hierarchical regression model to control for their effect. The first model showed that control variables did not affect innovation behavior significantly (Adj. $R^{2}=0.038, p>0.05$; Table 3). In the second step of the analysis, the independent variables were entered to the regression model. The second model showed that the independent variables significantly contributed to innovation behavior (Adj. $R^{2}=$ 0.506, $p<0.01$; Table 3). Both supplier collaboration in NPD $(\beta=0.225 ; p<0.001)$ and lead user collaboration in NPD $(\beta=0.430 ; p<0.001)$ significantly affected innovation behavior. Based on these results, hypotheses H1 and $\mathrm{H} 2$ are accepted.

\section{Conclusions}

This study investigated the effects of suppliers and lead users collaboration in NPD on innovation behavior in manufacturing companies in EU. The analysis revealed a strong positive relationship between the innovation behavior of a company and collaboration with both lead users and suppliers. The results emphasize the importance of external collaboration on innovation behavior. New ideas with high quality are not restricted to internal $\mathrm{R} \& \mathrm{D}$, but the innovation process can be accelerated and enhanced by involving suppliers and lead users. In today's highly competitive environment, organizations can enhance their competitive advantage by focusing on external alliances and collaboration in NPD. External alliances enable manufacturers to increase and maintain competitive advantages in spite of declining R\&D budgets.

The study highlighted the essential role of lead user collaboration in NPD. It is not surprising that lead user collaboration showed higher impact on innovation behavior than supplier collaboration. Lead users are invaluable sources of new innovative ideas that are represent the future needs of the markets. Companies missing lead user collaboration may not be able to catch up with competitors in the era of globalization and high environmental

Table 3. Hierarchical regression model: company’s innovation performance.

\begin{tabular}{|c|c|c|c|c|c|}
\hline & \multicolumn{2}{|c|}{ Unstdized Coeffs } & \multirow{2}{*}{$\begin{array}{c}\begin{array}{c}\text { Stdized } \\
\text { Coeffs }\end{array} \\
\text { Beta }\end{array}$} & \multirow{2}{*}{$\mathrm{t}$} & \multirow{2}{*}{ Sig. } \\
\hline & $\beta$ & Std. Error & & & \\
\hline \multicolumn{6}{|l|}{ Step 1} \\
\hline (Constant) & 5.033 & 0.546 & & 11.343 & 0.000 \\
\hline Company size (number of employees) & -0.039 & 0.045 & -0.020 & -0.534 & 0.864 \\
\hline Company age & -0.021 & 0.048 & -0.138 & -1.997 & 0.180 \\
\hline Length of relationship & 0.028 & 0.045 & 0.112 & 1.971 & 0.298 \\
\hline r & 0.105 & & & & \\
\hline$R^{2}$ & 0.050 & & & & \\
\hline Adjusted $R^{2}$ & 0.038 & & & & \\
\hline Regression $F$-value & 4.616 & & & & \\
\hline \multicolumn{6}{|l|}{ Step 2} \\
\hline (Constant) & 4.014 & 0.411 & & 9.184 & 0.000 \\
\hline Company size (number of employees) & -0.039 & 0.033 & -0.069 & -0.488 & 0.832 \\
\hline Company age & -0.035 & 0.039 & -0.036 & -0.638 & 0.735 \\
\hline Length of relationship & 0.147 & 0.174 & 0.074 & 2.064 & 0.364 \\
\hline Supplier Collaboration & $0.330^{*}$ & 0.176 & $0.225^{*}$ & 2.296 & 0.001 \\
\hline Lead Users Collaboration & $0.450^{*}$ & 0.065 & $0.430^{*}$ & 3.931 & 0.000 \\
\hline $\mathrm{r}$ & 0.763 & & & & \\
\hline$R^{2}$ & 0.568 & & & & \\
\hline Adjusted $R^{2}$ & 0.506 & & & & \\
\hline$R^{2}$ Change & 0.468 & & & & \\
\hline Regression $F$-value & 7.954 & & & & \\
\hline
\end{tabular}

Note: ${ }^{*} \mathrm{p}<0.001$. 
uncertainly. All in all, external alliances are proved by our study to have a significant impact on innovation behavior and performance.

The limitation of this paper is that only one innovation behavior scale was applied. Further research is needed to investigate the effects of supplier and lead user collaboration on different innovation types, such as product and process. Furthermore, only one respondent was targeted from each manufacturing company. A future study with multiple respondents from each company may increase the generalizability of the results. Finally, case studies are needed to determine critical success factors in involving suppliers and lead users in NPD activities.

\section{References}

[1] Abdallah, A. and Matsui, Y. (2007) Just In Time Production and Total Productive Maintenance: Their Relationship and Impact on JIT and Competitive Performances. In: Proceedings of the 9th International Decision Sciences Institute Conference, Bangkok, 18 p.

[2] Abdallah, A.B., Anh, P.C. and Matsui, Y. (2016) Investigating the Effects of Managerial and Technological Innovations on Operational Performance and Customer Satisfaction of Manufacturing Companies. International Journal of Business Innovation and Research, 10, 153-183.

[3] Chesbrough, H.W. (2003) Open Innovation: The New Imperative for Creating and Profiting from Technology. Harvard Business School Press, Boston.

[4] Elmquist, M., Fredberg, T. and Ollila, S. (2009) Exploring the Field of Open Innovation. European Journal of Innovation Management, 12, 326-345. http://dx.doi.org/10.1108/14601060910974219

[5] Cohen, W. and Levin, R. (1989) Empirical Studies of Innovation and Market Structure. In: Schmalensee, R.C. and Willig, R., Eds., Handbook of Industrial Organization, Elsevier, Amsterdam, 1059-1107.

[6] Dahlander, L. and Gann, D. (2010) How Open Is Innovation? Research Policy, 39, 699-709. http://dx.doi.org/10.1016/j.respol.2010.01.013

[7] Frishammer, J., Grönlund, J. and Sjödin, D. (2010) Open Innovation and the Stage-Gate Process: A Revised Model for New Product Development. California Management Review, 52, 106-132. http://dx.doi.org/10.1525/cmr.2010.52.3.106

[8] Jessup, L., Reed, R. and Storrud-Barnes, S. (2012). How Open Innovation Affects the Drivers of Competitive Advantage: Trading the Benefits of IP Creation and Ownership for Free Invention. Management Decision, 50, 58-73. http://dx.doi.org/10.1108/00251741211194877

[9] Al-Zu'bi, Z.M.F. and Tsinopoulos, C. (2012) Suppliers versus Lead Users: Examining Their Relative Impact on Product Variety. Journal of Product Innovation Management, 29, 667-680. http://dx.doi.org/10.1111/j.1540-5885.2012.00932.x

[10] Al-Abdallah, G.M., Abdallah, A.B. and Bany Hamdan, K. (2014) The Impact of Supplier Relationship Management on Competitive Performance of Manufacturing Firms. International Journal of Business and Management, 9, $192-202$. http://dx.doi.org/10.5539/ijbm.v9n2p192

[11] Von Hippel, E. and Katz, R. (2002) Shifting Innovation to Users via Toolkits. Management Science, 48, 821-833. http://dx.doi.org/10.1287/mnsc.48.7.821.2817

[12] Littler, D., Leverick, F. and Bruce, M. (1995) Factors Affecting the Process of Collaborative Product Development: A Study of UK Manufacturers of Information and Communications Technology Products. Journal of Product Information Management, 12, 16-32. http://dx.doi.org/10.1016/0737-6782(94)00025-B

[13] Mikkola, J.H. and Skjøtt-Larsen, T. (2004) Supply-Chain Integration: Implications for Mass Customization, Modularization and Postponement Strategies. Production Planning \& Control: The Management of Operations, 15, 352-361. http://dx.doi.org/10.1080/0953728042000238845

[14] Scott, S. and Bruce, R. (1994) Determinants of Innovative Behavior: A Path Model of Individual Innovation in the Workplace. The Academy of Management Journal, 37, 580-607. http://dx.doi.org/10.2307/256701

[15] Freeman, C. (1974) The Economics of the Industrial Revolution. Pinter, London.

[16] Sanchez, R. and Mahoney, J.T. (1996) Modularity, Flexibility and Knowledge Management in Product and Organization Design. Strategic Management Journal, 17, 63-76. http://dx.doi.org/10.1002/smj.4250171107

[17] Van Echtelt, F.E.A., Wynstra, F., Van Weele, A.J. and Duysters, G. (2008) Managing Supplier Involvement in New Product Development: A Multiple-Case Study. Journal of Product Innovation Management, 25, 180-201. http://dx.doi.org/10.1111/j.1540-5885.2008.00293.x

[18] Vega-Jurado, J., Gutierrez-Gracia, A., Fernandez-de-Lucio, I. and Manjarres-Henriquez, L. (2008) The Effect of External and Internal Factors on Firms’ Product Innovation. Research Policy, 37, 616-632. http://dx.doi.org/10.1016/j.respol.2008.01.001

[19] Al-Zu’bi, Z.M.F. (2010) Collaboration in Mass Customisation: Exploring the Impacts of Suppliers and Lead Users. 
VDM Verlag, Saarbrücken.

[20] Von Hippel, E. (1998) Economics of Product Development by Users: The Impact of "Sticky” Local Information. Management Science, 44, 629-644. http://dx.doi.org/10.1287/mnsc.44.5.629

[21] Bidault, F., Charles, D. and Butler, C. (1998) New Product Development and Early Supplier Involvement (ESI): The Drivers of ESI Adoption. International Journal of Technology Management, 15, 49-70. http://dx.doi.org/10.1504/IJTM.1998.002593

[22] Dowlatshahi, S. (1997) The Role of Product Design in Designer Buyer-Supplier Interface. Production and Planning Control, 8, 522-532. http://dx.doi.org/10.1080/095372897234867

[23] Frohlich, M.T. and Westbrook, R. (2001) Arcs of Integration: An International Study of Supply Chain Strategies. Journal of Operations Management, 19, 185-200. http://dx.doi.org/10.1016/S0272-6963(00)00055-3

[24] Foxall, G.R. and Johnston, B. (1987) Strategies of User-Initiated Product Innovation. Technovation, 6, 77-102. http://dx.doi.org/10.1016/0166-4972(87)90013-7

[25] Handfield, R.B., Ragatz, G.L., Petersen, K.J. and Monczka, R.M. (1999) Involving Suppliers in New Product Development. California Management Review, 42, 59-82. http://dx.doi.org/10.2307/41166019

[26] Phan, A.C., Abdallah, A.B. and Matsui, Y. (2011) Quality Management Practices and Competitive Performance: Empirical Evidence from Japanese Manufacturing Companies. International Journal of Production Economics, 133, 518-529. http://dx.doi.org/10.1016/j.ijpe.2011.01.024

[27] Al-Zu’bi, Z.M.F., Al-Lozi, M., Dahiyat, S., Alshurideh, M. and Al Majali, A. (2012) Examining the Effect of Quality Management Practices on Product Variety. European Journal of Economics, Finance and Administrative Sciences, 1, 1-19

[28] Al-Zu’bi, Z.M.F. and Tsinopoulos, C. (2012) An Outsourcing Model for Lead Users: An Empirical Investigation. Production Planning and Control, 24, 1-10.

[29] Al-Zu’bi, Z.M.F., Tarawneh, E., Abdallah, A.B. and Fidawi, M. (2015) Investigating Supply Chain Integration Effects on Environmental Performance in the Jordanian Food Industry. American Journal of Operations Research, 5, $247-257$. http://dx.doi.org/10.4236/ajor.2015.54019

[30] Frishammer, J., Grönlund, J. and Sjödin, D. (2010) Open Innovation and the Stage-Gate Process: A Revised Model for New Product Development. California Management Review, 52, 106-132. http://dx.doi.org/10.1525/cmr.2010.52.3.106

[31] Mikkola, J.H. (2003) Modularity, Component Outsourcing, and Inter-Firm Learning. R \& D Management, 33, $439-454$. http://dx.doi.org/10.1111/1467-9310.00309

[32] Eisenhardt, K.M. and Tabrizi, B.N. (1995) Accelerating Adaptive Processes: Product Innovation in the Global Computer Industry. Administrative Science Quarterly, 40, 84-110. http://dx.doi.org/10.2307/2393701

[33] Luthje, C. and Herstatt, C. (2004) The Lead User Method: An Outline of Empirical Findings and Issues for Future Research. $R$ \& D management, 34, 553-568. http://dx.doi.org/10.1111/j.1467-9310.2004.00362.x

[34] Morrison, P.D., Roberts, J.H. and Von Hippel, E. (2000) Determinants of User Innovation and Innovation Sharing in a Local Market. Management Science, 46, 1513-1527. http://dx.doi.org/10.1287/mnsc.46.12.1513.12076

[35] Lilien, G.L., Morrison, P.D., Searls, K., Sonnack, M. and Von Hippel, E. (2002) Performance Assessment of the Lead User Idea-Generation Process for New Product Development. Management Science, 48, 1042-1059. http://dx.doi.org/10.1287/mnsc.48.8.1042.171

[36] Eliashberg, J., Lilien, G.L. and Rao, V.R. (1997) Minimizing Technological Oversights: A Marketing Research Perspective. In: Garud, R., Nayyar, P.R. and Shapira, Z.B., Eds., Technological Innovation: Oversights and Foresights, Cambridge University Press, Cambridge, 214-230. http://dx.doi.org/10.1017/cbo9780511896613.014

[37] Hamann, U. (1999) Health Awards Recognise Innovation and Performance: The Significance of Innovation in the Semiconductor Industry for Performance in Chip Card Applications. The Lamp. 56, Part, 11, 23 Issue Id Parts 11.

[38] Lonsdale, R.T., Noel, N.M. and Stasch, S.F. (1996) Classification of Sources of New Product Ideas. In: Rosenau Jr., M.D., Ed., PDMA Handbook of New Product Development, John Wiley and Sons, New York, 179-194.

[39] Phan, A.C., Abdallah, A.B. and Matsui, Y. (2011) Quality Management Practices and Competitive Performance: Empirical Evidence from Japanese Manufacturing Companies. International Journal of Production Economics, 133, 518-529. http://dx.doi.org/10.1016/j.ijpe.2011.01.024

[40] Abdallah, A. and Matsui, Y. (2009) The Impact of Lean Practices on Mass Customization and Competitive Performance of Mass-Customizing Plants. Proceedings of the 20th Annual Production and Operations Management Society (POMS) Conference, Orlando, 1-4 May 2009. http://dx.doi.org/10.13140/2.1.2445.8563

[41] Tang, J., Pee, L. and Iijima, J. (2013) Investigating the Effects of Business Process Orientation on Organizational Innovation Performance. Information \& Management, 50, 650-660. http://dx.doi.org/10.1016/j.im.2013.07.002

[42] Hair, J.R., Black, J.F., Babin, B.J. and Anderson, R.E. (2010) Multivariate Data Analysis. 7th Edition, Macmillan, New York. 